\title{
The Minimalist and Maximalist Approaches in the TEFLIN: Towards the Empowerment of the General Indonesian Learners of English
}

\author{
Asim Gunarwan \\ Universitas Indonesia, Jakarta
}

\begin{abstract}
The point of departure of this paper is an assumption that the teaching of English in Indonesian public schools has not yielded the minimum expected result: English learners have not been empowered with the reading skill in English, let alone the other skills. Given that English has an elevated role to play in the new millennium, Indonesian learners should be empowered in this language for wider communications. Two approaches are proposed, namely (1) the minimalist approach, in which reading ability is the sole objective of the teaching of English to students in general, the corrolary being the use of the translation method; and (2) the maximalist approach, in which "ordinary" students are taugh along the line of the notion of Little English (much discussed in the 60's and 70 's), whereas "the cream of the cream" are tutored in a special programme designed to make them English-Indonesian bilinguals. Hence, a new language policy of Indonesia should be developed and English curricula be reviewed and a national commission on the TEFLIN be set up to look into the matter in more depth and to suggest ways in which the teaching of this language in schools can really empower the learners in the context of human resources development.
\end{abstract}

Key words: Minimalist and Maximalist Approaches, Indonesia learners of English, empowerment

This paper presupposes that, generally speaking, the teaching of English in Indonesian public schools has not yielded the expected result, namely equipping the students with the ability or capacity in English to enable them to act or perform effectively in this language. The line of thinking underlying this paper is based on two basic assumptions, i.e. (1) that, especially as a result of globalisation, the community of nations is 
becoming more and more globalised and that, therefore, a language is needed which will function as a language for wider communications (LWC), and (2) the Indonesian language at this juncture cannot function as an LWC, and therefore in order for us to be able to partake in world discourse in an effective manner, we still need the English language as an LWC. The corrolary of these two basic assumptions is that the Indonesian society and, by implication, English learners in schools in general, need to be more empowered in terms of the mastery of this uncontested LWC. This paper attempts to identify two approaches in which English learners can be empowered: the minimalist and the maximalist approach.

\section{GLOBALISATION: SOME IMPLICATIONS}

The last decade of the second millennium was marked with an important phenomenon popularly known as globalisation, the repercussions of which have been felt up to now and probably continue to be felt until quite some time in the forseeable future. According to Waters (1995), it refers to a process whereby nations are becoming more and more so interconnected in terms of economy, culture, and, by implication, politics that country boundaries become "fuzzy". In Waters' words, globalisation is "[a] social process in which the constraints of geography on social and cultural arrangements recede and in which people become increasingly aware that they are receding" (1995: 3). This is made possible owing to the fast progress in advanced technology, particularly information, transportation and communication technologies. When, and if, the process succeeds, what we have is a fully globalised world, in which there is only "one community and one culture ... which may be harmoniously or disharmoniously integrated" (ibid).

That there are people who use this term in its narrow sense, namely referring it to the arena of economy only, is no surprise. This is because what has been very salient lately is the application of the term to the activities of a number of countries to globalise their economies, as can be inferred from the arrangements of the Uruguay Round-GATT, WTO, NAFTA, AFTA and APEC. Bijlani (1994) has even written a book on globalisation solely from the economic perspective, without mentioning that the term is also applicable to two other arenas, namely culture and politics. In the arena of the culture, globalisation implies modernisation; in the arena of politics it implies democratisation; and in the arena of economy it alludes to trade liberalisation.

The era of globalisation requires that nations join a global community of nations so integrated that, as alluded to above, economic, cultural, and political boundaries blur. Such a globalised community is characterised by the interdependence and, more importantly, the competition among its members such that the status of a member nation in that community, whether it is central or peripheral, depends, to a large extent, on its competitive advantages rather than on its comparative advantages. The interdependence of nations implies that a language for wider communications (LWC) is needed for a member nation to function effectively in the discourse of the globalised community. The requirement that a member nation should have competitive edges implies that it should master science and technology, and for a developing member nation it further implies that it should master a language in which books on the latest development of science and technology are written. This boils down to the implication that a developing nation needs to master a language with which it can bolster up its human resources to a level enabling it to have a competitive edge among nations.

There are, needless to say, people who harbour doubts whether those implications are real. These people are perhaps influenced by the thinking of Naisbitt (1994), who believes that the more we become universal, the of Naisbitt (1994), who believes that that, more importantly, when English becomes the second language for most people, their mother tongue becomes more important and therefore more and more efforts will be made to maintain it. However, even if this is true, it does not deny the fact that the role of English will rise in the future, owing to or despite globalisation, especially as the result of the continuing progress in science and technology, mostly encoded in English. What seems to be true, then, is that in this twenty-first century, nations, especially developing ones, cannot afford not to master English, because of globalisation or otherwise.

For Indonesia, a developing country, one pertinent question at this juncture is whether it can rely on its national language, Bahasa Indonesia, as a means to elevate the quality of its human resources to enable it to become globally competitive. By the same token, another pertinent question is whether Indonesian can function as an LWC in a globalised community so that Indonesia can rely on it to function effectively in the global discourse 


\section{THE ADEQUACY OF INDONESIAN}

\section{Linguistic Adequacy}

As a means to develop Indonesian human resources, there is no reason for assuming that the Indonesian language cannot be used. A competitive nation needs to have a people with good discipline, and Indonesian is sufficiently adequate for that purpose: it can certainly be relied on. Likewise, for the purpose of intellectualising the people, this national language can surely be given credence to. However, when it comes to developing human resources optimally in order for Indonesia to have a competitive edge among nations as well as a non-peripheral status in the globalised community, it seems logical to say that, at this time, Indonesia still needs an LWC with which to expedite the transfer of science and technology. This is in a way because of the scarcity of books on the latest development of technology (and science) which are written in Indonesian. Moreover, the translation of the books into Indonesian will not seem to help much because, as the experience has shown, the progress of science and technology always outdoes the speed in which books are translated into Indonesian.

There are people who believe that Indonesian has the potentials of becoming an LWC. First, there are linguists who believe that this language, other things being equal, is "easier" to learn - which is why, according to some quarters, this language has become the "preferred" foreign language studied as an elective in many schools in Australia, especially in the Northern Territory. Secondly, Indonesian - or Malay has already assumed the LWC function in much of the region of Southeast Asia, a territory as wide as the whole Europe. Malay is the national language of Indonesia, Malaysia, and Brunei Darussalam, and is used by a significant number of people in Singapore, southern Thailand, and some southern islands of the Philippines. The question at this juncture is whether this language can go out of its traditional territory to assume the function of LWC in its wider sense, nearing the function of the languages now referred to as "real" LWC's.

According to Brosnahan (1963), as quoted by Hermosa (1986), the spread of a language to new territories resulted, in the past, from a language being imposed on conquered peoples. The language of the conquerors then gradually became the language of the conquered peoples through the interplay of social, political and military forces. Brosnahan cites four factors which accompanied the process of the adoption by the conquered peoples of the language imposed upon. These are: first, the language was originally imposed by military authority; second, it was maintained for at least several centuries by the same authority; third, the language was introduced to a multilingual area; fourth, knowledge of the imposed language gave its new users advantages or benefits (Hermosa, 1986:1).

In this modern time, in which no nation can claim territories which do not lawfully belong to it, the question of Indonesian being imposed on other peoples, by military forces or otherwise, is inconceivable. What is conceivable is the possibility of Indonesian being learned as a school subject. Even for this, Indonesian should compete with other languages. This is because in this economy-minded era, everything seems to be calculated on the cost-benefit analysis: for the cost I am going to incur, what benefits will I get?

One of the many considerations to be made before a school decides to teach a certain foreign language is, it can be hypothesised, whether the language is adequate as a means of modern communication, namely whether it is capable of being used as a means of communication in various topics and forms of discourse which characterise modern states. The objective yardstick in this respect is whether the language has had two features, namely: (1) the easiness with which to express modern concepts and (2) the accuracy or precision with which modern concepts are expressed.

Indonesian is a relatively "young" language and efforts towards modernising it continues to be made. A Brunei Darussalam-IndonesiaMalaysia language council has been established with a view, among other things, to coining new terms for new scientific and technological concepts - a seemingly never-ending undertaking. Thanks to the language council, thousands of new terms have been coined and agreed on, and Indonesian/ Malay is now adequate as the medium of modern discourse, be it on Cartesian philosophy or astrophysics.

A question remains, however, namely whether in that respect Indonesian is homologous with English, an established LWC, for example. Gunarwan (1997) compares the linguistic adequacy between these two languages and concludes, cautiously, that there "are indications which show that English is more adequate than Indonesian". One case in point is that an English phrase such as the rich daughter of the 
president has a precise meaning, not ambiguous, in that it is the daughter, not the president, who is rich. By comparison, the rendering of that phrase into Indonesian, anak perempuan presiden yang kaya itu, is ambiguous in that the one who is rich can be the daughter or the president. Similarly, the rendering of a one-word term translucent into a two-word term tembus cahaya (literally meaning 'penetrable by light') in the following example also shows some ambiguity in the Indonesian rendering of the English sentence.

(E) A translucent object lets some light through, but it scatters the rays so much that whatever is on the side cannot be seen clearly.

(I) Benda yang tembus cahaya memungkinkan cahaya melaluinya, tetapi benda yang demikian itu menyemburatkan berkas cahaya sehingga apa pun yang berada di balik benda itu tidak dapat dilihat dengan jelas.

The rendering of translucent into tembus cahaya (or letus, for example) is not effective. In English, an object which is penetrable by light can be translucent or transparent; the meanings are different.

The Indonesian rendering of the English sentence above suggests that, in terms of syllables, Indonesian is less "efficient" than English. To express the same idea, Indonesian needs about 74 syllables, while English needs only about 33 syllables, less than one half of the length of the Indonesian equivalence. Part of the "inefficiency" of the Indonesian rendering is the fact that the grammatical rule of Indonesian at present does not allow the use of the third-person pronoun $i a$ to refer to inanimate objects and therefore English it (one syllable) in the example above has to be translated into benda yang demikian itu (9 syllables).

What the foregoing implies is (1) that the mordernisation of Indonesian, in particular the development of its lexicon, should be accelerated and (2) that at this time it is difficult for Indonesian to compete with English as a school subject in the curricula of many a country. The latter implication further implies that Indonesian has to go a long, long way before it has a chance of becoming a real LWC, not a limited LWC as it is now. Still a further implication is that in this era of global competition, more than ever, Indonesia has to rely on English in order to be globally competitive. Geolinguistically, Indonesian is not yet comparable to English.

\section{Geolinguistic Adequacy}

Mackey (1973) brings up three concepts of geolinguistics and posits that languages have different forces. The force of a language, he argues, is the function of three factors, namely language power, language attraction, and language pressure, each of which has indicators which can be quantified for comparison purposes. Language power has six indicators, namely demography, dispersion, mobility, economy, ideology and culture; language attraction has three indicators, namely status attraction, territorial attraction and interlingual attraction; and language pressure has two indicators, namely behavioural traits and concept acculturation.

Gunarwan (1997) compares the geolinguistic adequacy between Indonesian and English and the result shows that the latter is geolinguistically more adequate than the former, as can be inferred from Table 1 below.

Mackey quantifies demography on the basis of the total number of the speakers of the language concerned, the per capita income of the country or countries speaking the language, and the relative advancement of the technology of the country or countries concerned. In this regard, all indications seem to point to the fact that English is geolinguistically more competitive than Indonesian. In the first place, English speakers far outnumber the approximately 250 million Indonesian/Malay speakers. Secondly, all in all, the average national per capita income of Englishspeaking countries, is higher than that of Indonesian/Malay-speaking countries. Thirdly, the former are technologically more advanced than the latter, as evidenced by the fact that the transfer of technology is in the direction of the latter, not vice versa.

Table 1 The Result of the Comparison of the Geolinguistic Adequacy of English (E) and Indonesian (I)

\begin{tabular}{|c|c|c|c|}
\hline No. & Language Force & Indicator & Comparison Result \\
\hline \multirow[t]{6}{*}{1.} & Language power & (1) Demography & $E>I$ \\
\hline & & (2) Dispersion & $E>I$ \\
\hline & & (3) Mobility & $E>I$ \\
\hline & & (4) Economy & $\mathrm{E}>\mathrm{I}$ \\
\hline & & (5) Ideology & $\mathrm{E}=\mathrm{I}(?)$ \\
\hline & & (6) Culture & $E>I$ \\
\hline \multirow[t]{3}{*}{2.} & Language attraction & (1) Status attraction & $\mathrm{E}>\mathrm{I}$ \\
\hline & & (2) Territorial attraction & $\mathrm{E}>\mathrm{I}$ \\
\hline & & (3) Interlingual attraction & $?$ \\
\hline \multirow[t]{2}{*}{3.} & Language pressure & (1) Behavioural traits & $\mathrm{I}>\mathrm{E}$ \\
\hline & & (2) Concept acculturation & $\mathrm{I}>\mathrm{E}$ \\
\hline
\end{tabular}

Source: Gunarwan (1997) 
In terms of dispersion, English also outdoes Indonesian/Malay by a large margin. While the former is spoken in almost all four corners of the world, thanks to British imperialism in the past, the latter is spoken only in the corner of Southeast Asia.

Economy as an indicator in Mackey's notion of geolinguistics refers to the economic productions of a country. In this respect, there are reasons to believe that English-speaking countries at this time outweigh Indonesian/Malay-speaking countries. The same seems to be true with respect to the mobility indicator which, according to Mackey, refers to how many of a country's citizens visit other countries and in what distances per year (measured from the country concerned to the country or countries visited).

The culture indicator is measured in terms of the number of book titles produced by a country a year, and in this respect English, the language of many advanced countries, outweighs Indonesian/Malay perhaps by a larger margin. Just compare, for example, the number of book titles in English in all Indonesian libraries with the number of book titles in Indonesian in all American libraries.

The ideology indicator refers to the language of ideology (such as Russian used to be the medium of marxism) or that of liturgy (such as Latin and Arabic). Perhaps only in this regard that English does not outweigh Indonesian, both languages not being languages of liturgy.

There is an indicator which points to the tendency that English outweighs Indonesian, even among Indonesians, in terms of attraction. This is evident from the results of a research study on English and Indonesian language attitudes using the matched guise technique with 126 subjects, all Indonesians, in Jakarta, Bandung, and Palangkaraya (Gunarwan, 1993). The results are presented in Table 2, from which it can be inferred that English is perceived as more prestigious than Indonesian by Indonesians.

As can be seen in this table, the English guise (representing the English language) is rated higher by the subjects than the Indonesian guise (representing the Indonesian language), the overall mean values being 3.85 and 3.31 respectively. It is interesting to note that only in terms of keramahan (friendliness) that the Indonesian guise outweighs the English guise, the former being rated 4.03 and the latter 3.12 .

The interlingual attraction indicator refers to the linguistic distance between two languages, namely whether or not they belong to the same
Table 2 Mean Values of Ratings by Subjects $(\mathrm{N}=126)$ on Eleven traits of the English and Indonesian Guise

\begin{tabular}{|r|l|c|c|}
\hline \multirow{2}{*}{ No. Trait } & \multicolumn{2}{|c|}{ Mean Value } \\
\cline { 3 - 4 } & & Indonesian Guise & English Guise \\
\hline 1. & Cleverness & 3.02 & 3.91 \\
2. & Wisdom & 3.68 & 4.33 \\
3. & Honesty & 2.73 & 3.66 \\
4. & Educatedness & 3.14 & 4.52 \\
5. & Humour & 3.85 & 3.04 \\
6. & Self-confidence & 3.55 & 3.98 \\
7. & Status & 2.87 & 3.76 \\
8. & Friendliness & 4.03 & 3.12 \\
9. & Leadership & 3.26 & 3.94 \\
10. & Discipline & 2.91 & 4.22 \\
11. & Sense of Responsibility & 3.41 & 3.87 \\
& Overall Mean & 3.31 & 3.85 \\
\hline
\end{tabular}

Source: Gunarwan (1993)

language family. Indonesian and English being linguistically unrelated, we can assume that the latter does not outweigh the former and vice versa in this respect.

Originally, there was little territorial attraction between these two languages. Indonesian/Malay was, and still is, the language of the Malay Archipelago and English was the language of England, two distant places. But English has spread to all corners of the world, not excepting Indonesia, and therefore the "territorial" attraction of this powerful LWC is increasingly greater in this republic. It culminated when the Indonesian government adopted a "policy" to allow English to be taught at the elementary school, albeit on a non-compulsory basis.

Whether or not English territorial attraction becomes language pressure in Indonesia is an academic question. At present, however, the pressure of English upon Indonesian is weak compared to that upon Malay in Singapore, for instance. So it seems.

What also seems to be true is that by and large the behavioural traits of Indonesians are still "influenced" by their national language or even by their local languages. This also applies to concept acculturation as a geolinguistic indicator. 


\section{CURRICULAR IMPLICATIONS}

The era of world competition demands that, lest alienated, Indonesia join a community of nations so integrated that economic, cultural and political boundaries, as alluded to earlier, become "blurry". In this regard, Indonesia needs to master a powerful LWC to function effectively in the global community, and that powerful LWC is English. By the same token, English is also needed to elevate the quality of Indonesian human resources to a level high enough to enable Indonesia to have competitive edges in this era of competitiveness. It may be worth noting that in terms of human resources quality, as can be inferred from the UNDP human development index (HDI), that of Indonesia is the lowest in the ASEAN region (Mustopadidjaja, 1997: 9).

Khomsan (2000) quotes the latest UNDP report, which shows that whereas the HDI's of other countries tend to rise, that of Indonesia has declined as can be inferred from the HDI's in Table 3.

Table 3 Human development indexes of a number of countries

\begin{tabular}{|ll|l|l|l|l|l|}
\hline \multirow{2}{*}{ No. Country } & \multicolumn{5}{|c|}{ HDI } \\
\cline { 3 - 6 } & & $\mathbf{1 9 9 6}$ & $\mathbf{1 9 9 7}$ & $\mathbf{1 9 9 8}$ & $\mathbf{1 9 9 9}$ & $\mathbf{2 0 0 0}$ \\
\hline 1. & Indonesia & $\mathbf{1 0 2}$ & 99 & 99 & 105 & 109 \\
2. & Vietnam & 121 & 121 & 122 & 110 & - \\
3. & Philippines & 95 & 98 & 98 & 77 & - \\
4. & Thailand & 52 & 59 & 59 & 67 & - \\
5. & Malaysia & 53 & 60 & 60 & 56 & - \\
6. & Brunei & 36 & 38 & 33 & 25 & - \\
7. & Singapore & 34 & 26 & 28 & 22 & - \\
8. & Japan & 3 & 7 & 8 & 4 & - \\
\hline
\end{tabular}

Source: Khomsan (2000)

Most probably, the decline of Indonesia's HDI (from the 99th rank in 1998 to the 105th in 1999) was owing to the economic crisis which has befallen us. The same assumption can be made as regards Thailand, whose HDI declined from the 59th to the 67 th over the same period of time. However, what is surprising is that the HDI's of the Philippines, Malaysia, Brunei Darussalam, Singapore, and even that of Vietnam, went up in the same period of time, despite being under the same sway of the Asian crisis.
Given that the HDI is the function of three parameters, namely education, health (as reflected by life expectancy), economy (as reflected by national per capita income), Indonesia's HDI can rise if the quality of our education increases. By the same token, if the quality of our English teaching goes up, our HDI will, eventually, go up, too. If this rationale is acceptable, then it is the responsibility of each and every one of us in the domain of TEFLIN to do our utmost to make English teaching in our public schools a success. And one measure of success would be the degree in which our high school leavers are empowered in the English language skills.

There are people who believe that when we talk about education, English education or otherwise, we should take into account what the UNESCO has formulated regarding education. To educate, according to this world agency, is to develop individuals (i.e. children) to learn how to think, how to live, and how to become their self-beings. People differ in perceiving how we educate our students: enabling them or equipping them with the knowledge and skills with which they will develop themselves. If we agree that to teach English is to equip our students with the knowledge and skills in English to enable them to develop their self-beings, a pertinent question at this juncture is to what extent we have succeeded in equipping them with the requisite skills? To what degree have we succeeded in empowering our students?

If for instance we can generalise the results of the TOEFL administered to a large number of candidates (who are sarjanas from nationwide universities) for overseas scholarships managed by the Overseas Training Office of BAPPENAS, we can infer that the teaching of English in Indonesia has not produced the desired results. Of the 453 candidates who sat for the TOEFL in 2000 (up to August), the average score was 371 . We can infer from this how low the quality of our English teaching is if we consider that the candidates have been taught English for six years in the high school and one or two semesters in the university. Given that the admission TOEFL score to US universities is 550, a score of 371 shows that candidates generally still have to go a long, long way to be admitted to an English-medium university. According to the Overseas Training Office official in charge of administering the TOEFL, it takes about eleven months of highly intensive tuition ( 8 hours daily, 5 days in a week) to raise a candidate's score of 450 to 550 
Alwasilah (2000:63) uses a sumple method of interpreting TOEFL scores. If a score begins with figure 3 , he states, the corresponding English mastery of the person who has taken the TOEFL is elementary; a score beginning with figure 4 impleis intermediate mastery; and a score beginning with figure 5 implies advanced mastery. This interpretation may be taken with a grain of salt by other scholars since it seems a little bit too generous. Too generous or not, however, an average TOEFL score of 371 achieved by our sarjanas is something that should make a wry face on the part of all of English teachers in Indonesia.

What is said in the foregoing regarding the poor English performance of our sarjanas seems to point to the fact that the quality of the teaching of English in Indonesia is indeed low, if not very low. Subject to verification from reliable research, even the first objective of English teaching, namely reading ability in the language, is not generally achieved. Thus, in this era of global competition, the first question to ask, and answer, is why English teaching in Indonesia has failed to produce commendable results - despite the funds and forces incurred. Perhaps there are factors which synergistically have given rise to the failure: Maybe there is one determining factor. What this implies is that a research project towards that end is indeed imperative at this turn of the twenty-first century.

More importantly, maybe the philosophy of our education should be re-assessed and re-formulated. By the same token, the vision in the teaching of English in Indonesia should be re-focused for all English teaching practitioners to see. For one thing, we cannot use the vision of the last century to guide us to live in this new century, when a great deal of things have changed. The questions to answer are: what is our present vision as regards the teaching of English? What do we see in the horizon? What mission is put on our shoulders to arrive at what we see? How is this mission spelt out to strategies, action plans, curricula, etc? Perhaps we need to sit down together to discuss what our education philosophy is and how this is translated into the vision and mission of the teaching of English in Indonesia. What I wish to say at this point is that there may be some truth in saying that the lack of success in our general education, is that it is not underpinned by a clear philosophy of education on which vision is formulated.

On a lower plane, there are those who believe that the failure of English teaching in Indonesia is due to the fact that the number of students in each class is large. If this is indeed the case, then one possible solution would be that the English class be divided into smaller groups, each to be taught by one (qualified) teacher. The corollary would be that new English teachers should be trained and appointed. This would be a very expensive undertaking especially during, and following, the economic crisis. But that is the risk which Indonesia has to bear if it wants to function effectively and to compete strongly in the globalised community of nations.

If that proposition is deemed too expensive to put into practice, what seems to be practicable would be to reduce the objectives of English teaching in Indonesia to one, namely only reading ability. This is what call the minimalist approach. In the first place, not all Indonesians need to be able to speak English. For many Indonesians, namely high school leavers, working knowledge in written English would be sufficient in the era of globalisation to use as a resource for personal development or to usher them to tertiary education where they learn science and technology in more depth. The reduced objective, namely reading ability in English only, would then require a radical change in the methods of teaching English. According to some experts in language teaching methodology, the most "simple" method in teaching a foreign language is the translation method, and therefore this method should be adopted in Indonesia in the context of the proposed minimalist objective. The teaching of grammar can be reduced to the essential minimum, the emphasis should be put on understanding written English, and translation exercises should be given priority. Students do not need to learn how to speak English; those (especially the gifted) who want to learn to speak this language can do it outside class, in a special intracurricular programme or private English schools, for example. By the same token, teachers' "energy" could be economised. They could be spared from the troubles of learning how to teach using the communicative approach, for example, and from using this approach in class. All they need is, assuming their mastery of English and Indonesian is good, some knowledge of the theory and practice of translation, which they can learn in in-service training programmes. All class meetings can be conducted in the form of translation exercises. The propagation of the results of Indonesian language planning can then ride piggyback in these translation exercises.

If this proposed minimalist objective chimes in with the wisdom of the authority, then a new curriculum needs to be built up and new English 
syllabi developed. Given that we have the courage to do that, one thing to consider is that the teaching of English in the high school needs to emphasize the teaching of vocabulary through the translation method as alluded to earlier. One view which could be adopted is the instrumentalist view (Nation and $\mathrm{Hu}, 2000: 2$ ), which sees vocabulary knowledge as being "a major prerequisite and causative factor in comprehension".

That would entail the teaching of a fixed number of words and care should be taken that most highly frequent words are given highest priority. Given that teaching tasks are made simple, the results can be better expected to reach the coup de maitre.

In this new century, not all Indonesians are required to master English to make Indonesia globally competitive. Suffice it for Indonesia to have a critical mass who have a good mastery of English, both oral and written, to enable them to "think globally and to act locally". In view of the present limited funds and forces, this could be achieved by resorting to a scheme for producing "the cream of the cream". In this scheme, talent scouting should be done with a view to identifying gifted students, who would then be given special, additional training in a special English programme designed to prepare them to compete internationally without English language hurdles. This is what I call the maximalist approach to TEFLIN. The "ordinary" students, meanwhile, would be taught in a general programme of English or else in a programme of Little English or Basic English often discussed in the 60's and 70's.

Another alternative would be to change the Indonesian system of education from monolingual to bilingual, in which certain subjects (such as mathematics, physics and biology) are taught in English, the rest in Indonesian. This is improbable to put into practice at present as it would require the hiring of very many English-speaking expatriate teachers.

Gunarwan (1999) proposes that a law should be passed to sanction English in Indonesia as a secondary (not second) language, Indonesian as the national language remaining the primary language. The rationale of the proposition is that such a law would provide the legal underpinning for more liberal room for English teaching. This proposition would entail the adoption a bilingual educational policy, like in the Philippines and Brunei Darussalam, in which certain subjects (such as mathematics, physics, and biology) are taught in English, whereas the rest are taught in Indonesian. However, given the present circumstances, the proposition would be certainly impossible to put into practice.
Moreover, there are people in Indonesia who have apprehension that the elevation of English into a "higher" position will have an adverse effect on Indonesian nationalism. Their reasoning is that the Indonesian language has a unifying function and constitutes an important component of Indonesian nationalism. Such apprehension can be neutralised, I believe, by saying that in the era of globalisation, nationalism tends to be de-emphasised and what matters more in this respect is national pride arising from a respectable position a nation enjoys in globalised community. At any rate, nationalism does not have to be based on language. In the words of Lebon, as quoted by Fishman (1974: 89), "to respect tradition is a condition of existence, to know how to disengage from it a condition of progress".

There are also people who assume that in order to have a good chance of success, language should be taught to children before they reach a "critical" age. There are pros and cons to this, but the Indonesian Department of National Education seems to believe that the assumption is true: now English may be taught at elementary school. It may bring about better results in the long run, but care should be taken not to teach language in a haphazard manner: the syllabus should be well designed, teaching materials well prepared, and teachers well trained. Otherwise, the teaching of English at this level will only defeat its purpose.

\section{CONCLUDING REMARKS}

The era in which English has an elevated role to play has quite a few of implications for Indonesia. One of them pertains to the need that this language be better mastered in order for this fourth most populous nation to become an effective member of a global community. English should be mastered by Indonesia not only in the context of national development but also, more importantly, in the context of enabling Indonesia to have competitive edges worldwide. More than ever, English is needed not only as a means of international communication, but also as a means, direct or indirect, of elevating the quality of Indonesian human resources to the optimum, that is, until this nation has acquired what Kanter, as quoted by Kristiadi (1997:52), refers to three C's: concept, competence, and connection, the last one referring to networking.

Another implication of the elevated role of English in the human resources development in Indonesia has at present is that efforts should 
be made towards creating a critical mass who will be able to speak and write in English - in short to be bilingual in Indonesia and English.

What seems to be imperative for Indonesia at this juncture is to set up an English language commission to be charged with a duty to review the language philosophy of Indonesia, the vision of the teaching of English, the position of English vis-a-vis Indonesian, the objectives of the teaching of English and, by implication, the outlines of a new English curriculum with all its ramifications.

In terms of objectives, it would be in Indonesia's advantage to be bilingual in Indonesian and English in the long run, hopefully not in the nottoo-remote future. This vision needs focusing, the blueprints for achieving the objectives need designing, the agenda needs fixing, and the action plans need developing.

\section{REFERENCES}

Alwasilah, A. Chaedar. 2000. Perspektif Pendidikan Bahasa Inggris di Indonesia (The Perspectives of English Education in Indonesia). Bandung: CV Andira. Biljani, Hiru. 1994. Globalisation: An Overview. Singapore: Heinemann Asia. Brosnahan, L.F. 1963. Some Historical Cases of Language Imposition. In John Spencer [Ed.]. Language in Africa. (pp. 7-24) Cambridge: CUP.

Fishman, Joshua A. 1974. Language Modernization and Planning in Comparison with Other Types of National Modernization and Planning. In Joshua A. Fishman [Ed.]. Advances in Language Planning. (pp. 79-102) The Hague: Mouton.

Gunarwan, Asim. 1999. Globalisation and the teaching of English in Indonesia. Paper presented at the RELC Seminar. Singapore, 19-21 April.

Gunarwan, Asim. 1997. Kepadaan Relatif Bahasa Indonesia Menjelang Abad ke21 (The Relative Adequacy of the Indonesian Language by the $21^{\text {st }}$ Century). Paper presented at the Seventh National Seminar on Indonesian Language and Literature, Medan, 7-9 July.

Gunarwan, Asim. 1993. Bahasa Asing sebagai Kendala Pembinaan Bahasa Indonesia (Foreign Language as a Barrier to the Development of Indonesian). Paper presented at the Sixth Congress of the Indonesian Language, Jakarta, 28 October-2 November.

Hermosa, Eleanor E.E. 1986. Filipino English: A Study in Contextualization. Unpublished Ph.D. Dissertation. National University of Singapore

Khomsan, Ali. 2000. Peringkat SDM Kita (The Rating of Our Human Resources). The Kompas. 29 September, p. 4.
Kristiadi, J.B. 1997. Perspektif Administrasi Publik Menghadapi Tantangan Abad 21 (sic) (Public Administration Perspectives in Facing the Challenges of the $21^{\text {st }}$ Century). Jurnal Administrasi dan Pembangunan, Vol. 1, No 2. 49-67.

Mackey, William F. 1972. Three Concepts for Geolinguistics. Montreal: Centre international de recherches sur le bilinguisme.

Mustopadidjaja, A.R. 1997. Transformasi Manajemen-Menghadapi Globalisasi Ekonomi (Management Transformations in the Wake of Economic Globalisation). Jurnal Administrasi dan Pembangunan, Vol. 1, No. 1. 28-46. Naisbitt, John. 1994. Global Paradox. New York: Avon Books.

Nation, Paul and Hu Hsueh-chao. 2000. Unknown Vocabulary Density and Reading Comprehension. http://www.vuw.ac.nz/lals/staff/paul_nation/ marcella.htm.

Waters, Malcom. 1995. Globalization. London and New York: Routledge. 